\title{
Piotr Blicharz
}

\section{Wykorzystywanie modelu luk jakości w zarządzaniu jakością usług restauracyjnych}

\section{Kod JEL: M31, M42}

Słowa kluczowe: usługa, jakość, Servqual, luka jakości, usługi gastronomiczne

Streszczenie. W artykule przedstawiono, na tle rozważań teoretycznych, wyniki badań percepcji jakości usług na rynku usług gastronomicznych w wybranym powiecie w województwie lubelskim. Badanie wykonano w trzech etapach: przez niezależnego audytora, wśród klientów oraz wśród pracowników restauracji. W badaniach wykorzystano metodę Servqual, dostosowując ją do specyfiki usług gastronomicznych.

\section{Wprowadzenie}

Na Zachodzie Europy już od lat 80., a w Polsce od lat 90. stale wzrasta zainteresowanie doskonaleniem jakości obsługi w celu nie tylko przyciągnięcia nowego, ale również utrzymania obecnego klienta. Ocena jakości wykonywanych usług nadal jest znacznie trudniejsza od oceny jakości produktu, mimo istnienia wielu metod prowadzenia takich pomiarów. Jednym ze sposobów uzyskania wyników jest metoda Servqual, opracowana przez A. Parasurmana, V.A. Zeithamla i L. Berry'ego (Prussak, 2003, s. 116). Polega ona na porównaniu wykonywanych usług z opinią i oczekiwaniami klienta. Autorzy ci, na podstawie przeprowadzonych wywiadów z usługobiorcami, wyodrębnili pięć założeń co do jakości usługi. Pierwszym z nich jest materialność, do której zalicza się pracowni- 
ków, wyposażenie lokalu czy też środki transportu. Kolejnym kryterium jest niezawodność, którą określono jako zdolność do wykonania danej usługi w sposób solidny. Trzecie założenie to wrażliwość, czyli podejście pracowników do wykonywanej pracy, czas realizacji przez nich zamówienia oraz postawa wobec klienta. Pewnością zaś określa się wzbudzenie u klienta zaufania. Natomiast przez empatię rozumie się wykazanie zainteresowania klientem oraz zrozumienie i zaspokojenie jego potrzeb.

Celem niniejszego opracowania jest przedstawienie analizy jakości usług gastronomicznych w wybranym powiecie województwa lubelskiego z wykorzystaniem metody Servqual i wskazanie na przykładzie wybranej restauracji obszarów wymagających doskonalenia. Jak wynika z analizy literatury, większość zaprezentowanych wyników badań zazwyczaj dotyczy analizy luki postrzegania usługi idealnej w porównaniu do usługi realnej. Jakość usługi została zbadana przez zebranie opinii od trzech grup osób, a mianowicie: audytora, klientów oraz pracowników restauracji. Badanie przeprowadzono zatem w trzech etapach. W pierwszym etapie jakość usługi została poddana ocenie audytora, w drugim klientów, natomiast $\mathrm{w}$ ostatnim etapie oceny dokonali pracownicy restauracji. Następnie obliczono zakres luki postrzegania w tych grupach.

Badanie przeprowadzono przy użyciu zmodyfikowanego kwestionariusza ankiety używanego w metodzie Servqual. Użyto w nim 21 determinant opisujących jakość usługi gastronomicznej. Na podstawie przeprowadzonych badań i uzyskanych wyników można stwierdzić, że użyta metoda pozwala w łatwy sposób wskazać, w jakich obszarach menedżerowie restauracji powinni doskonalić usługi.

\section{Przegląd literatury}

Próba oceny satysfakcji klienta z poziomu jakości świadczonych usług z użyciem metody Servqual jest dość popularnym narzędziem wykorzystywanym do pomiaru i oceny jakości usług (Gajewska, 2014), np.:

- usług edukacyjnych (Lupo, 2013),

- usług finansowych świadczonych przez internet (Carrasco, 2012),

- usług w zakresie sprzedaży internetowej i detalicznej (Rao, 2011),

- usług informatycznych (Roses, Hoppen, Henrique, 2011),

- usług bankowych, fryzjerskich i dentystycznych (DeMoranville, Bienstock, 2003),

- usług turystycznych (Lin, Ren, Liao, Zheng, 2014),

- usług drogowego transportu chłodniczego (Gajewska, 2014).

W swoich badaniach związanych z jakością w usługach gastronomicznych z metody Servqual skorzystali również: S. Markovic, J. Komsic, M. Stifanic (2013, s. 176), H. Safdar Butt, M. Murtaza (2016, s. 55-65), S. Markovic, S. Raspor (2010, s. 195-209), S.A. Malik, L.H. Jaswal, S. Alam, M. Tahir, M. Awan (2013, s. 187- 
200), R. Korzeniowska-Ginter, J. Repińska (2011, s. 82-91), V. Patrício, R.P. Leal, Z.L. Pereira (2006). Można zatem zauważyć, że dość bogata jest literatura w tej tematyce.

\section{Metoda badań}

Metoda Servqual została zastosowana w celu weryfikacji luk między stanem postrzegania jakości usługi przez audytora, klientów oraz przez personel w wybranej restauracji. Wskazane różnice należy zniwelować przez wprowadzenie zmian doskonalących, mających pomóc w lepszym prosperowaniu restauracji. $\mathrm{W}$ badaniu zrezygnowano $\mathrm{z}$ dokonania pomiaru różnic, jakie występują pomiędzy poziomem jakości w ocenie klienta a jego oczekiwaniami względem niej.

W badaniu wzięli udział: audytor, 45 klientów (do badania wytypowano 200 przypadkowych klientów restauracji, lecz tylko 45 zgodziło się podczas wyznaczonego okresu badania wypełnić kwestionariusz ankiety) oraz pracownicy restauracji (po 5 z każdej restauracji). Audytor został wprowadzony do badania w celu uzyskania obiektywnej opinii, nienacechowanej prywatnymi względami. Przychodził on do restauracji w roli tajemniczego klienta, nie uprzedzając personelu o przeprowadzanym badaniu. W badaniu wykorzystano kwestionariusz ankiety, w którym zastosowano determinanty dostosowane do wymagań branży. Badanie zostało przeprowadzone $\mathrm{w}$ jednym $\mathrm{z}$ powiatów województwa lubelskiego, w którym zlokalizowano sześć podobnych pod względem oferty dużych restauracji oferujących usługi gastronomiczne oraz hotelowe. Ponadto nie są to restauracje sieciowe, a okres ich funkcjonowania na rynku wynosi co najmniej 4 lata. Audytor dokonał oceny jakości usług zgodnie z kwestionariuszem ankiety. Równolegle prowadzono badanie wśród klientów (bezpośrednio po wyjściu z restauracji) oraz wśród pracowników.

\section{Analiza wyników badań}

Do oceny wybrano 21 determinant przedstawionych w tabeli 1 zakwalifikowanych do jednej z pięciu grup. W kwestionariuszu nie dokonano ważenia poszczególnych determinant, co z jednej strony może być wadą, gdyż nie ukazuje, które $\mathrm{z}$ nich są istotniejsze, $\mathrm{z}$ drugiej jednak strony jest zaletą, ponieważ w dążeniu do doskonałości restauracje powinny tak samo intensywnie wzmacniać wszystkie wskazane obszary.

Osoby biorące udział w badaniu oceniały każdą determinantę przy pomocy 7-stopniowej skali. Dla poszczególnych determinant obliczono oceny średnie, a wyniki zostały przedstawione w formie graficznej, ze wskazaniem luk między postrzeganiem poziomu jakości przez audytora i klientów, audytora i pracowników oraz klientów i pracowników. 
Tabela 1

Kwestionariusz Servqual

\begin{tabular}{|c|c|c|c|c|c|c|c|c|}
\hline \multirow{2}{*}{ Lp. } & \multirow{2}{*}{ Determinanty } & \multicolumn{7}{|c|}{ Ocena według skali Likerta } \\
\hline & & 1 & 2 & 3 & 4 & 5 & 6 & 7 \\
\hline \multicolumn{9}{|c|}{ Materialność } \\
\hline 1 & Otoczenie restauracji jest przyjazne & & & & & & & \\
\hline 2 & Restauracja jest urządzona estetycznie & & & & & & & \\
\hline 3 & Krzesła, fotele oraz stoliki są czyste i zadbane & & & & & & & \\
\hline 4 & Kelnerzy są ubrani schludnie i elegancko & & & & & & & \\
\hline \multicolumn{9}{|c|}{ Niezawodność } \\
\hline 5 & $\begin{array}{l}\text { W restauracji usługa jest wykonywana z odpowiednią sta- } \\
\text { rannością }\end{array}$ & & & & & & & \\
\hline 6 & $\begin{array}{l}\text { Kelnerzy dokładają starań, by wykonać usługę sprawnie } \\
\text { i terminowo }\end{array}$ & & & & & & & \\
\hline 7 & Restauracja nie serwuje dań złej jakości & & & & & & & \\
\hline \multicolumn{9}{|c|}{ Wrażliwość } \\
\hline 8 & $\begin{array}{l}\text { Pracownicy restauracji właściwie rozpoznają potrzeby } \\
\text { klienta }\end{array}$ & & & & & & & \\
\hline 9 & Kelnerzy szybko sprzątają brudną zastawę & & & & & & & \\
\hline 10 & Restauracja realizuje zamówienia w zadeklarowanym czasie & & & & & & & \\
\hline 11 & $\begin{array}{l}\text { Kelnerzy informują klienta o czasie oczekiwania na zamó- } \\
\text { wienie }\end{array}$ & & & & & & & \\
\hline \multicolumn{9}{|c|}{ Pewność } \\
\hline 12 & Kelnerzy witają klienta z uśmiechem na twarzy & & & & & & & \\
\hline 13 & Personel jest uprzejmy względem klienta & & & & & & & \\
\hline 14 & Kelnerzy posiadają dużą wiedzę na temat serwowanych dań & & & & & & & \\
\hline 15 & Pracownicy restauracji słuchają krytyki klientów & & & & & & & \\
\hline \multicolumn{9}{|c|}{ Empatia } \\
\hline 16 & Personel zawsze $\mathrm{z}$ chęcią pomoże klientowi & & & & & & & \\
\hline 17 & $\begin{array}{l}\text { W restauracji jest miła atmosfera, klient czuje się komfor- } \\
\text { towo }\end{array}$ & & & & & & & \\
\hline 18 & $\begin{array}{l}\text { Pracownicy restauracji podchodzą do klienta w sposób in- } \\
\text { dywidualny }\end{array}$ & & & & & & & \\
\hline 19 & Restauracja ma odpowiednie dla klienta godziny otwarcia & & & & & & & \\
\hline 20 & Klient restauracji czuje się mile widziany & & & & & & & \\
\hline 21 & $\begin{array}{l}\text { Personel wykazuje elastyczne podejście przy niestandardo- } \\
\text { wych prośbach }\end{array}$ & & & & & & & \\
\hline
\end{tabular}

Źródło: opracowanie własne.

W dalszej części artykułu przedstawiono wyniki badań dla jednej wybranej restauracji. Na rysunkach 1-zaprezentowano wyniki ocen audytora, klientów oraz pracowników zawarte w poszczególnych grupach (materialność, niezawodność, wrażliwość, pewność oraz empatia). Wskazano także wielkość luki w postrzeganiu jakości usług. 
Na rysunku 1 przedstawiono wyniki związane $\mathrm{z}$ determinantami opisującymi obszar materialności usługi. Wyraźnie zauważalna jest różnica w postrzeganiu jakości usługi pomiędzy pracownikami a klientami oraz audytorem w zakresie estetyki urządzenia restauracji (determinanta $\mathrm{nr} 2$ ) oraz czystości krzeseł oraz stołów (3). W odniesieniu do ubioru pracowników (4) oraz przyjazności otoczenia (1) nie wystąpiły znaczące różnice, chociaż sami pracownicy, w odróżnieniu od klientów i audytora, dostrzegali, że czystość nie jest na najwyższym poziomie.

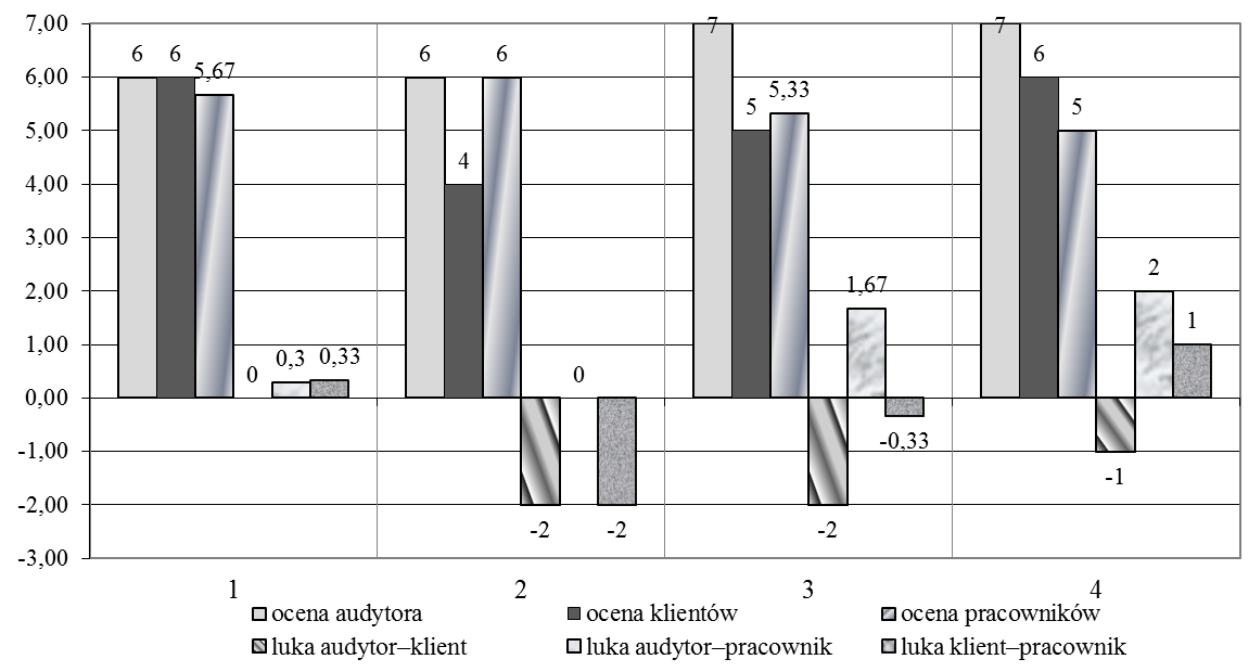

Rysunek 1. Postrzeganie materialności

Źródło: opracowanie własne.

W obszarze niezawodności (rys. 2) widoczna jest różnica w postrzeganiu jakości dań (7) i sprawności obsługi kelnerskiej (6). W obrębie tego miernika powinna nastąpić wyraźna poprawa, ponieważ według oceny audytora i klientów znajduje się on na niskim poziomie. Staranność usługi została oceniona wyżej przez audytora niż przez klientów i pracowników (5).

Jak wynika z rysunku 3, największa rozbieżność pomiędzy percepcją badanych osób w grupie „wrażliwość” wystąpiła w przypadku determinanty dotyczącej właściwego rozpoznawania potrzeb klienta (8). Istotne różnice wystąpiły między oceną tego czynnika przez audytora, który określił poziom jakości usługi jako niski, a pracownikami, którzy ocenili go jako wysoki. Najbardziej zbliżone oceny uzyskano w przypadku ostatniej w omawianej grupie determinanty, dotyczącej informowania klienta o czasie oczekiwania na realizację zamówienia (11). Najniżej czynnik ten ocenili klienci, jednak różnice w ocenie między grupami badanych nie są znaczące, a poziom jakości w każdej z nich określono jako wysoki. 
W przypadku dwóch pozostałych determinant, odnoszących się do czasu sprzątania brudnej zastawy (9) oraz wykonywania usług w deklarowanym czasie (10), największe rozbieżności występują między oceną klientów i pracowników. Oceny audytora i klientów są w tym przypadku zbliżone i oscylują w granicach średniego poziomu jakości.

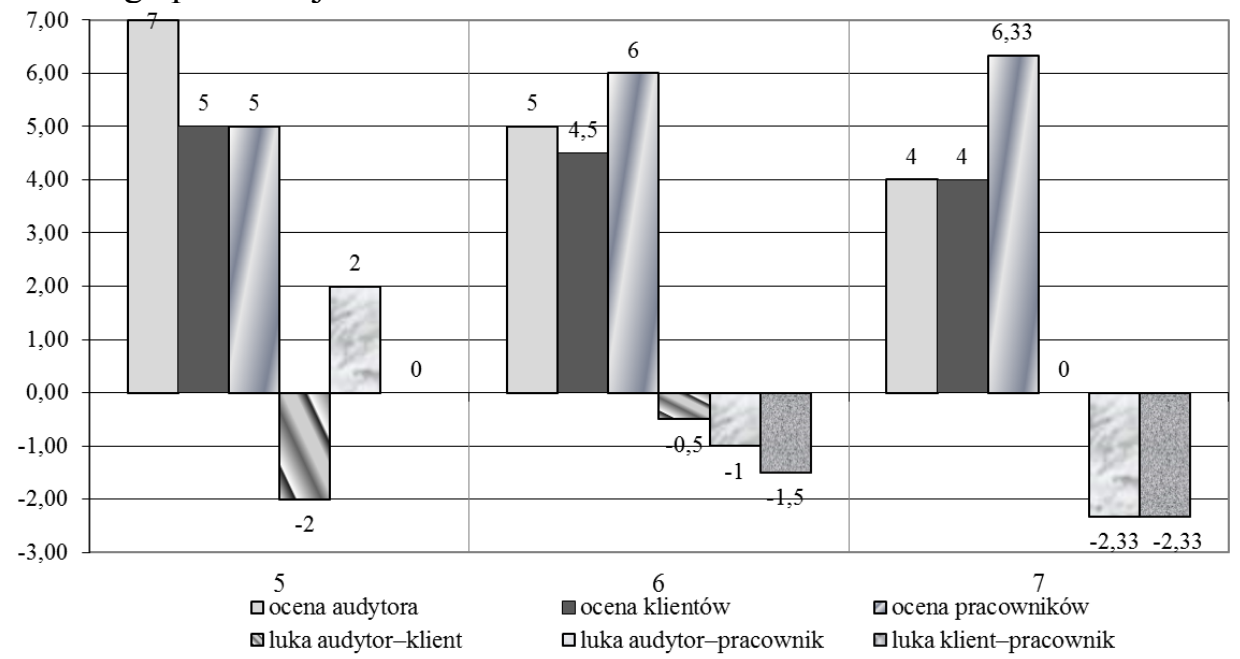

Rysunek 2. Postrzeganie niezawodności

Źródło: opracowanie własne.

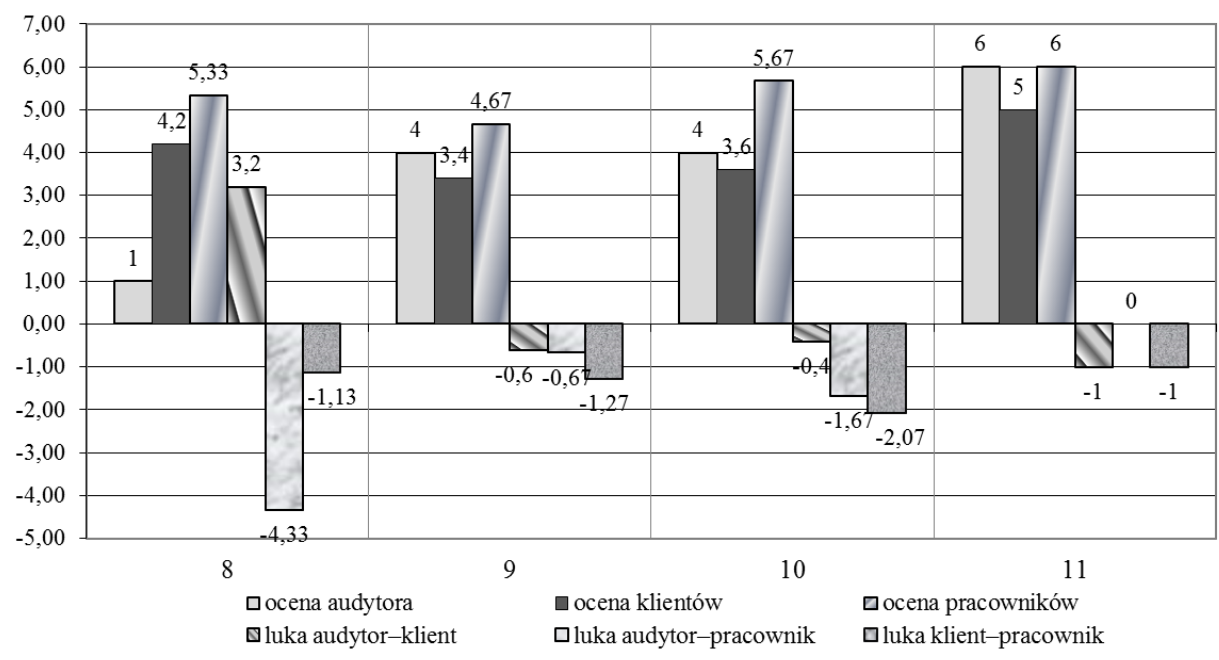

Rysunek 3. Postrzeganie wrażliwości

Źródło: opracowanie własne. 
Oceny dotyczące kolejnej grupy determinant wskazanych w obszarze ,pewność" są stosunkowo dobre (rys. 4). Uprzejmość kelnerów (13) oraz ich wiedza na temat serwowanych dań (14) zostały ocenione najniżej przez klientów. Z kolei opinia audytora jest istotnie niższa od opinii pozostałych grup w przypadku determinanty, w której badani oceniali, czy kelnerzy witają klientów z uśmiechem na twarzy (12). Można zauważyć, że opinie pracowników są z reguły bardziej pozytywne od pozostałych.

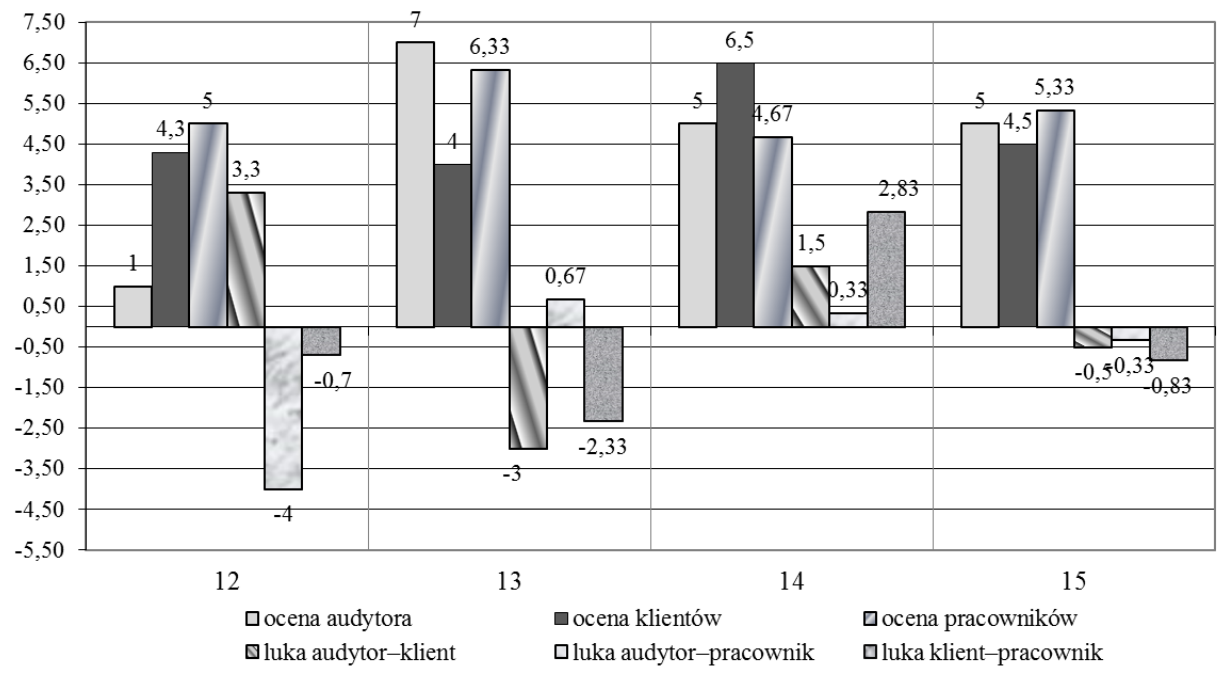

Rysunek 4. Postrzeganie pewności

Źródło: opracowanie własne.

W ostatniej grupie determinant (rys. 5) największe dysproporcje występują w ocenie dwóch parametrów: chęci udzielania pomocy klientom przez personel restauracji (16) oraz indywidualnego podejścia do klienta (18). W obu przypadkach luki są największe w grupach klient-pracownik oraz audytor-pracownik. Prawidłowość ta, chociaż z mniejszym nasileniem stopnia zróżnicowania ocen, jest aktualna także w odniesieniu do kolejnych determinant (19-21). Oceny pracowników były w przytoczonych przykładach istotnie wyższe niż te wystawione przez audytora i klientów. Osoby objęte badaniem były zgodne, że w restauracji panuje miła atmosfera, a klient czuje się komfortowo (17). Miało to przełożenie na niewielkie luki jakości w obrębie tego parametru.

Po pogrupowaniu szczegółowych cech jakości w wymienionych wyżej pięciu obszarach Servqual obliczono średnią arytmetyczną, pozwalającą na przedstawienie profilu oceny klientów, pracowników oraz audytora (rys. 6). Wyodrębnione profile jakości usług jednoznacznie wskazują, że klienci aż w czterech obszarach (oprócz pewności) oceniają usługę gorzej niż pracownicy czy audytor. 
Najsurowiej ocenili empatię, a najlepiej materialność usługi. Dodatkowo należy podkreślić, że żaden z omawianych obszarów nie został w pełni doceniony przez klientów, a zauważalna rozbieżność w obszarze empatii będzie trudna do zniwelowania.

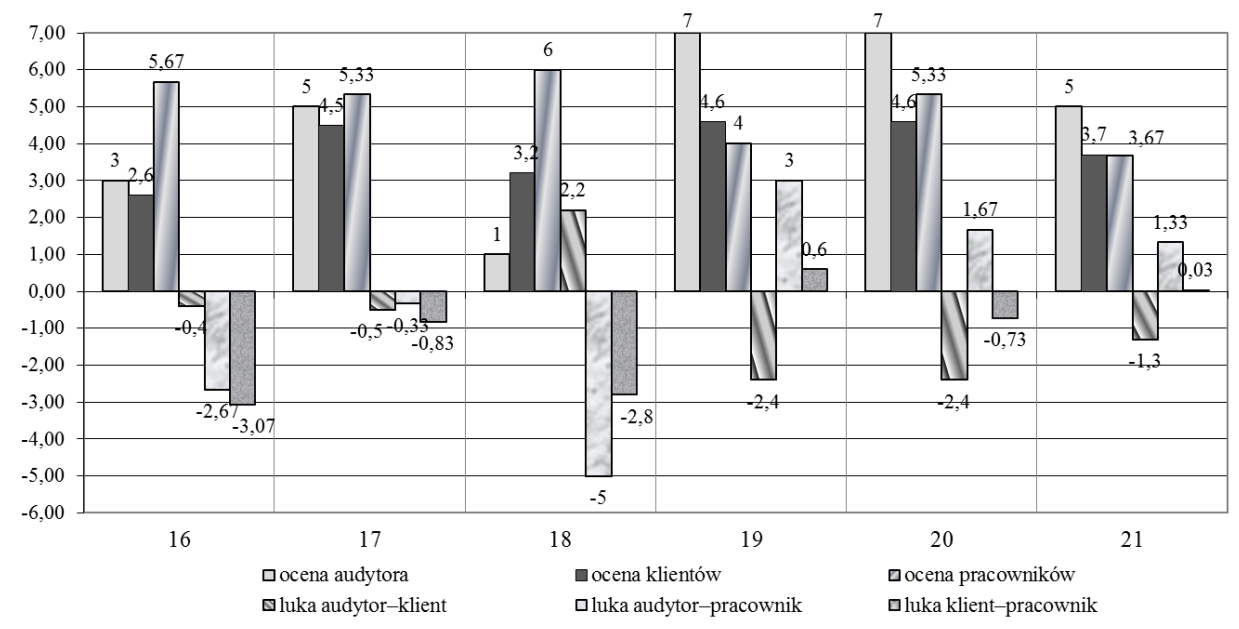

Rysunek 5. Postrzeganie empatii

Źródło: opracowanie własne.

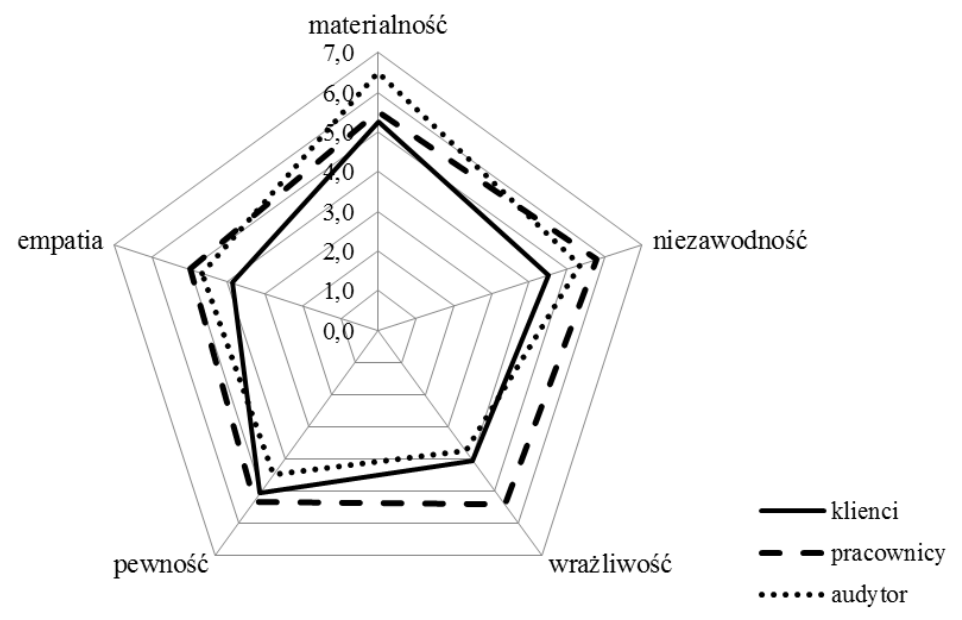

Rysunek 6. Zbiorcze zestawienie obszarów jakości usługi

Źródło: opracowanie własne. 


\section{Podsumowanie}

W badaniu zaprezentowano praktyczne wykorzystanie metody Servqual do oceny jakości usług restauracyjnych. Wybór metody oraz zakres badawczy zostały dopasowane do celu badania. Należy zauważyć, że mimo uniwersalności prezentowanej metody, nie jest to gotowe narzędzie, które można bezkrytycznie zastosować w każdej branży. Usługi restauracyjne charakteryzują się dużą różnorodnością i oczekiwania klientów mogą być diametralnie różne. Dlatego też system oceny jakości usług i zakres działań doskonalących powinien być dobierany indywidualnie.

Na podstawie uzyskanych wyników można stwierdzić, że właściciele restauracji w procesie doskonalenia jakości usług powinni zadbać przede wszystkim o budowanie pomiędzy pracownikiem a klientem relacji opartej na empatii. Serdeczne witanie gości, uprzejma postawa personelu oraz wiedza na temat serwowanych potraw to ważne czynniki, które budują pozytywny wizerunek firmy i wymagają poprawy. Pracownicy powinni chętnie pomagać klientom, kierując się przy tym indywidualnym i elastycznym podejściem. Jest to jeden z głównych środków do wzbudzenia w gościu poczucia, że jest mile widziany. Pracownicy powinni zostać przeszkoleni w zakresie prawidłowej obsługi klienta. Należałoby także weryfikować ich poziom znajomości oferty restauracji. Ponadto do innych istotnych elementów, które powinny ulec poprawie, można zaliczyć: właściwe rozpoznawanie potrzeb klienta, sprawność obsługi oraz zwiększenie dbałości o czystość w restauracji.

\section{Bibliografia}

Carrasco, R.A., Munoz-Leiva, F., Sanchez-Fernandez, J., Liebana-Cabanillas, F.J. (2012). A model for the integration of e-financial services questionnaires with SERVQUAL scales under fuzzy linguistic modelling. Expert Systems with Applications, 39 (14), 11535-11547.

DeMoranville, C., Bienstock, C.C. (2003). Question order effects in measuring service quality. International Journal of Research in Marketing, 20 (3), 217-231.

Gajewska, T. (2014). Analiza jakości usług logistycznych w transporcie chłodniczym z wykorzystaniem metody Servqual. Logistyka, 6, 3710-3715.

Korzeniowska-Ginter, R., Repińska, J. (2011). Ocena porównawcza usług gastronomicznych na terenie Gdyni z wykorzystaniem metody Servqual. Zeszyty Naukowe Uniwersytetu Szczecińskiego, 694, Problemy Zarzadzania, Finansów i Marketingu, 22, 81-92.

Lin, S., Ren, P., Liao, Z., Zheng, W. (2014). Research on evaluation of travel service quality for Jiuzhaigou Valley on the basis of Servqual. WIT Transactions on Information and Communication Technologies, 3.

Lupo, T. (2013). A fuzzy ServQual based method for reliable measurements of education quality in Italian higher education area. Expert Systems with Application, 40 (17), 7096-7110.

Malik, S.A., Jaswal, L.H., Alam, S., Tahir, M., Awan, M. (2013). Measuring service quality perceptions of the customers of restaurants in Pakistan. International Journal for Quality Research, 7 (2), 187-200. 
Markovic, S., Komsic, J., Stifanic, M. (2013). Measuring service quality in city restaurant settings using DINESERV scale. W: Recent Advances in Business Management and Marketing, Dubrownik: WSEAS Press.

Markovic, S., Raspor, S. (2010). Measuring perceived service quality using servqual: a case study of the Croatian Hotel Industry. Management, 5 (3), 195-209.

Patrício, V., Puga, R.P., Pereira, Z.L. (2006). Applicability of SERVQUAL in restaurants: an exploratory study in a Portuguese resort. Enterprise and Work Innovation Studies, 2, 127-136.

Prussak, W. (2003). Zarządzanie jakością. Wybrane elementy. Poznań: Wydawnictwo Politechniki Poznańskiej.

Rao, S., Goldsby, T.J., Griffis, S.E., Iyengar, D. (2011). Electronic Logistics Service Quality (e-LSQ): Its Impact on the Customer's Purchase Satisfaction and Retention. Journal of Business Logistics, 2 (32), 167-179.

Roses, L.K., Hoppen, N., Henrique, J.L. (2009). Management of perceptions of information technology service quality. Journal of Business Research, 62 (9), 876-882.

Safdar, Butt, H., Murtaza, M. (2011). Measuring Customer Satisfaction w.r.t Restaurant Industry in Bahawalpur. European Journal of Business and Management, 3 (5), 54-64.

\section{Using the Model of Quality Gaps in the Quality Management of Restaurant Services}

Keywords: service, quality, Servqual, quality gaps

Summary. The article presents, on the background of theoretical considerations, the results of the perception of the quality of services on the market catering services in selected district in Lubelskie voivodeship. The survey was carried out in three stages by an independent auditor, among customers and among employees of the restaurant. The study used Servqual method, adapting it to the specific of catering services.

Translated by Piotr Blicharz

\section{Cytowanie}

Blicharz, P. (2016). Wykorzystanie modelu luk jakości w zarządzaniu jakością usług restauracyjnych. Marketing i Zarzadzanie, 3 (44), 289-298. 